\title{
The Effect of REAP Strategy on Reading Comprehension
}

\author{
Andarini Permata Cahyaningtyas ${ }^{1, *}$, Ali Mustadi $^{2}$ \\ ${ }^{1}$ Elementary School Teacher Education Department, Faculty of Teacher Training and Education, \\ Sultan Agung Islamic University, Semarang, Indonesia \\ ${ }^{2}$ Primary Education Department, Post Graduate Program, Yogyakarta State University, Yogyakarta, \\ Indonesia
}

\begin{abstract}
The purposes of this study are to find out the effect of REAP strategy on reading comprehension of the fifth grade elementary students of third cluster of Kotagede Yogyakarta. The research method in this study was quasi-experimental with Pretest-Posttest Control Group Design. The population was all of fifth grade elementary students of third cluster of Kotagede Yogyakarta. The sample was fifth grade students of SD Baluwarti, SD Kotagede 1, and SD Kotagede 5 Yogyakarta that were establised by cluster random sampling technique. The data were collected using tests. The validity of the instrument was measured in terms of content and construct validity. The reliability of the instrument was stated good with the score of Cronbach's Alpha $=0,734$. The data of this study were analized by independent sample t-test and Manova with Hotteling's Trace formula. The result showed that REAP strategy gave a positive and significant effect on reading comprehension that is proved by the score of t-test $=4,914$ and 3,286 with sig $=0,000$ and 0,002 . Based on the result, it can be concluded that REAP strategy gives positive and significant effect on reading comprehension of the fifth grade elementary students of third cluster of Kotagede Yogyakarta.
\end{abstract}

\section{Introduction}

Reading process basicly has some steps, such as preparing, reading, giving responses, exploring text, and expanding interpretation [1]. This means students will get message by reading text and translate it into something they understand, so there are many understanding activity in their mind. This is confirmed by cognitive scientists who find facts in these last three decades that readers experience mental understanding process while reading text [2]. This shows that there are many cognitive components which involved in reading comprehension. Understanding process in reading is really entangled with the text students read. They need to connect the message they get from the text with prior knowledge they have had. Students can produce a new knowledge by this process, whereas

\footnotetext{
*Corresponding author: andarinipermata@unissula.ac.id
} 
their prior knowledge will be corrected because there is some mistake information, or expanded because of some new informations.

Reading comprehension basically is an activity to help students to comprehend text. Comprehension of text depends on 2 main things, reader and what they read[3]. Students are reffered to have comprehended the text if they can explain the main points of the text they have read without reading it again, and also they can make connections between the new information they get after reading and their prior knowledge. This is not easy for readers, especially children, so if they failed to connect their prior knowledge with the text, reading activity will become meaningless and boring[4].

Steps of reading comprehension are: 1) literal comprehension, readers need to process written information in the text; 2) interpretation comprehension, readers process information based on text, they need to understand what writer wants to say; 3) critical comprehension, students have to integrate their thought with facts in the text, and they need to evaluate their prior knowledge and experience so they are able to create new information; 4) creative comprehension, students develop their original idea based on the text and be creative to find any conclution or sollution writer presents on it[5].

Reading for understanding in elementary school, especially in fifth grade, sometimes is done in Indonesian Lesson only. In fact, comprehension through text is needed in every activity involved reading, eventhough the way to practice it is in language subject. It is like what teachers of fifth grade of third cluster of Kotagede said, that students still have difficulties in comprehending the text. They only read the text and when they are given some questions about the text, they will read it again from the start to look for the answers. The text is also sourced from Indonesian lesson book only, so their knowledge is less developed. Teachers were only using question and answer method in reading comprehension lesson because they haven't found a method or strategy for reading comprehension yet, encompassed REAP.

REAP (Read, Encode, Annotate, and Ponder) is one of reading comprehension strategy proven to have positive effect to increase students' comprehension while reading text[6]. REAP is defined as a strategy which helps reading process to create uncomplete meanings into coheren conclusion with students knowledge, guide students during and after reading process, and help students to be active readers who are able to understand and internalize the writer's idea they get while reading the text with or without the teacher's guidance [7$10]$.

In the first step, they read the text in silent. With silent reading, students will be independent readers who are able to reach higher level of literacy capability and academic success, which become prime standard on linguistic [11]. While reading, they will find some important points, they will encode it on their own language. This activity will help students to make some codes about information they get from the text in their long-term memory with some useful ways in every person [12]. After that, annotate it by writing the message, and then ponder what's the meaning of the text [13]. In fact, writing is an activity involves deep toughts, which improve students' ability to firm up their understanding [14]. REAP is expected to help students understand the text. REAP has some advantages such as students become active readers, help students to decipher writer's idea to become reader's by synthesizing into their own language, interpret writer's idea to be reader's, and find out student's thinking developing[15-17]. Based on this theory, it is regretted that the fifth grade teachers of the third cluster of Kotagede have not applied REAP yet, and did not know whether REAP has possitive effect on reading comprehension ability of their students or not. Because of this problem, this study aimed at finding out the effect of REAP strategy on reading comprehension to the fifth grade elementary students of third cluster of Kotagede. 


\section{Method}

\subsection{Research Design}

This study used quantitative approach, quasi-experiment method with pretest-postest control group design. There were two exprimental groups in this research such as the first and second exprimental group which were chosen by ramdom sampling.

\subsection{Time and Place}

This reseach was held on second semester of 2014/2015 school year, at March 5-24, 2015 on elementary schools of third cluster of Kotagede, Yogyakarta. Each of exprimental group had 8 times meeting with 1 times for pretest, 6 times for giving treatment, and 1 times for posttest.

\subsection{Participants}

Population in this study were 224 students of fifth grade of elementary schools of third cluster of Kotagede. Samples were decided by using cluster random sampling technique which appointed 3 classes, fifth grade of SDN Baluwarti as first exprimental group, SDN Kotagede I as the second exprimental group, and SDN Kotagede V as control group. The REAP strategy was implemented in the experimental group, and the control group was taught using underlining method. At the beginning of course, students have been given pretest, and at the end they were given posttest using the same instrument measurement.

\subsection{The Phases of the Research}

1. Teachers give some instructions about REAP strategy for students in experimental groups.

2. The learning process using REAP:
a. Use the text for course book or given by the teachers as reading material;
b. Read and then identify the main idea, key points, facts, orders, and sequences;
c. Take a short note based on the text;
d. Ponder the note they write whereas it was right or not.

3. Students were given exercises to find out how their skill on reading comprehension after using REAP strategy.

\subsection{Data Analysis Technique}

Data for this research were collected by using essay test of reading comprehension. The questions were arranged using Barret Taxonomy because it is trusted to be able to represent questions related to reading comprehension, and more detailed compared to the other taxonomies. The test contained 15 questions that consisted of stages of reading comprehension. Investigation was conducted to measure validity and reliability of the test tools. There were 40 students who were tested and 13 questions were analyzed by using SPSS program, and it was found to have score above $0.312\left(\mathrm{t}_{\text {table }}\right)$ for the validity test and 
0.785 for reliability test, so these results showed that the questions were valid and reliable.

This data was interpreted by using 0.5 significance level.

\section{Results and Discussion}

Post-data research was divided into pretest and postest data. In the pretest, there were 26 students who had been tested on the first experimental group, 27 on the second experimental groups, and 22 students on the control group. This is the result of pretest of reading comprehension:

Table 1. The Result of Pretest of Reading Comprehension

\begin{tabular}{|l|c|c|c|}
\hline \multicolumn{1}{|c|}{ Description } & Exprimental group I & Exprimental group II & Control Group \\
\hline Total Score & 170 & 175.13 & 140.51 \\
\hline Average score & 6.54 & 6.48 & 6.38 \\
\hline The Highest Score & 9.23 & 8.21 & 7.95 \\
\hline The Lowest Score & 6.55 & 5.13 & 4.87 \\
\hline
\end{tabular}

Pretest result on the first experimental group showed that the the highest score was 9.23 and the lowest was 6.55 , with the average was 6.54 . This was categorized as low score compared to the minimum score criteria of Indonesian subject at SDN Baluwarti which was 7.00. Meanwhile, the results of the pretest of the second experimental group showed that the highest score was 8.21 and the lowest was 5.13, with the average was 6.48 . This was categorized as low score compared to the minimum score criteria of Indonesian subjects at SDN Kotagede I which was 7.00. The control group also showed similar result. The highest score of the control group was 9.23 and the lowest was 6.55 , with the average was 6.54 . This was categorized as low scores compared to the minimum score criteria of Indonesian subject at SDN Kotagede 5 which was 7.00. These pretest results from three groups showed that there were no significant differences. This means that students' reading comprehension from experiment and control groups are no difference in the beginning.

However, posttest showed different result.

Table 2. Posttest of Reading Comprehension Result

\begin{tabular}{|l|c|c|c|}
\hline \multicolumn{1}{|c|}{ Description } & Exprimental group I & Exprimental group II & Control Group \\
\hline Total Score & 231.79 & 222.05 & 171.46 \\
\hline Average score & 8.58 & 8.22 & 7.47 \\
\hline The Highest Score & 10 & 9.74 & 8.97 \\
\hline The Lowest Score & 6.67 & 6.15 & 6.15 \\
\hline
\end{tabular}

Posttest result on the first experimental group showed that the highest score was 10 and the lowest was 6.67, with the average was 8.58. It indicated that their test results increased significantly compared to pretest results as much as 2.02 . Meanwhile, the result of the pretest of the second experimental group showed that the highest score was 9.74, and the lowest was 6.15 , with the average was 8.22 that also increased from the pretest score which 
was as much as 1.74. The control group also showed good result. The highest score of the control group was 8.97 and the lowest was 6.15 , with the average was 8.97 . This was 0.78 higher than the pretest average score. But this indicated that the posttest scores of control group also did not show any significant progress from pretest scores.

Table 3. Result of Hypothesis with Independent Sample T-test on Reading Comprehension

\begin{tabular}{|c|c|c|c|c|}
\hline Groups & T-test & Df & Sig & Note \\
\hline First Experimental & 4.914 & 48 & 0.000 & $\begin{array}{c}\text { There were significant } \\
\text { differences }\end{array}$ \\
\hline Second Experimental & 3.286 & 48 & 0.002 & $\begin{array}{c}\text { There were significant } \\
\text { differences }\end{array}$ \\
\hline
\end{tabular}

The data showed t-test result on the first experimental group was 4.914 and 3.286 on the second experimental group. Those results are more than $t_{\text {table }}=1.678$. The significant scores $<0.05$. These indicated that there were different effect between REAP strategy on experimental groups and underlining strategy on reading comprehension. So that, it could be concluded that REAP strategy had given more positive and significant effect on reading comprehension of the fifth grade students on third cluster of Kotagede Yogyakarta.

REAP strategy steps were proven to be able to help students to comprehend the text. Starting with reading, students absorbed the hidden meaning of the text. Silent reading can guide students to be independent readers who are able to increase their comprehension of the text. Then, students will encode the main points of the text, and then they reform some main point into their language. Students would involve actively in mental activity while they absorbed knowledge and information from what they read. This activity also sharpen their thinking to see something from the other perspective. The next was annotating which allow them to annotate some difficult words and those main points they thought will help them to understand. Annotating helped students to think straight to the points of the text. The last was pondering about the notes they had been written whether they are right or wrong. These steps were really helpful for them to comprehend the whole meaning of the text, go along with the text, and avoid to memorize words by words. These were different from the underlining strategy which made students repeating what words they had underlined to identify the main points of the text. It was attested that REAP was more effective than underlining strategy on reading comprehension.

\section{Conclusion}

REAP strategy had been proven to have effect on reading comprehension, so it can be applied on reading comprehension activities. REAP strategy can be one of learning strategy alternatives not only can be implemented for Indonesian subjects, but every subjects who need to comprehend some texts. The note the students make can also be used as material for independent-learning so they can be easier to understand the text-sourced subject such as Civic, Science, and Social Studies.

We acknowledge and sincerly thank the lecturers and the Head of of Primary Education Department of Postgraduate Program of Yogyakarta State University for their advice, which help us to complete this research. We are also very grateful for the support, cooperation and useful comments from our collagues. Their supports always encourage us to continue with the study. Finally we would like to thank to the Head of Elementary School Teacher Department in Sultan Agung Islamic University who has given us permission to present this research in GC-Tale of Undiksha. 


\section{References}

1. G.E. Tompkins \& K. Hoskisson, Language arts: content and teaching startegies (third ed.), (Englewood Cliffs: A Simon \& Schuster Company, 1995, 202-206).

2. M. Ness, JRCE, 25, 98.

3. J. Hayon, Membaca dan Menulis Wacana, (Jakarta: Gramedia, 2007, 55).

4. A.M. Glenberg, IEJEE, 4, 9, (2011).

5. D. Rubin, A Practical Approach to Teaching and Writing (second ed), (Danvers: John Wiley \& Sons, 1993, 196-197).

6. M. Tasdemir, J Soc Behav Pers, 38, 557 (2010).

7. M.G. Eannet \& A.V. Manzo, Journal of Reading, 19, 648.

8. Manzo \& Manzo, Content Area Reading, (Ohio: Merrill Publishing Company, 1990, 221).

9. M.R. Ruddel, Teaching Content Reading and Writing (4th ed), (Needham Height: Ally and Bacon, 2005, 261).

10. Y. Abidin, Strategi Membaca, (Bandung: Rizqy Press, 2010, 152).

11. K. P. Walker, Journal of Reading, 57, 185 (2013)

12. S. Schellenberg, M. Negishi, \& P. Eggen. Journal of Teaching Educational Psycology, 7, 18 (2011).

13. K.S. McKnight, The Teacher's Big Book Graphic Organizers, (San Fransisco: JosseyBass, 2010, 140).

14. J. Coeerey \& G. C. Rinnert, Journal of Visible Language, 47, 3 (2015).

15. M. Tasdemir, J Soc Behav Pers, 38, 554 (2010).

16. S.L. Strode, Journal of Reading, 36, 568 (1993).

17. Y.Abidin, Strategi Membaca, (Bandung: Rizqy Press, 2010, 153). 